\title{
INCENTIVES FOR PRIVATE INNOVATIONS - IS PUBLIC SUPPORT NECESSARY?
}

Do firms really need public support in order to offer product and process innovations? Recent articles and professional reports reflect the importance of public support for private innovations. The issue is actual and relevant both from scientific and practical points of view. Public support for actions aimed at developing crucial innovations is an example of creating institutional incentives for the desired behaviour of firms. The question of public support for innovations is critical for ongoing national and international policies in raising the innovativeness of economies. The main goal of the paper is to review the idea of public support for innovativeness and to verify its effects in European countries empirically, by using simple probit and bivariate probit models. This paper aims to provide a systematic analysis of the problem from an institutional perspective. The results of the analysis contribute to a better understanding of the nature of public spending on private innovations and the outcome of such innovation policies. It is also an added value to the discussion over actual public policies which has been so far inconclusive.

Keywords: innovation policy, public support, public policy, institutional economics

JEL Classifications: D22, O31, O32

DOI: 10.15611 aoe.2020.2.05

\section{INTRODUCTION}

Is public support for commercial innovative business activity really necessary? The authors pose this question with reference to the institutional frameworks of the role of the state in pro-innovative strategies of growth.

There is a broad literature on innovations. However, the terms of innovativeness and innovations still remain ambiguous. In a more practical dimension, while conducting analyses on innovations, one can reflect on simplified and well-grounded methodology (as is done in this paper).

Schumpeter (1960) was one of the first who included innovations in regular analyses. From his viewpoint, issues like introducing a new product or new type of a product or new processes (mainly of production), could be classified as innovations. Another type of innovative activity may be setting up a new market for a particular sector.

* Faculty of Economic Sciences, University of Warsaw. 
One of the most popular and commonly used methodologies for analyses on innovations is the Oslo methodology (OECD 2005). In this context, innovations are identified as applying new or significantly improved goods (products), processes, organizational and marketing methods and interactions with regulatory surroundings. The following four types of innovations are popularly mentioned in the literature: product innovations, process innovations, organizational innovations and marketing innovations.

Introducing new products or services (or improved ones) to a market means conducting a product innovation. Process innovations are based on new or improved method of production, or other processes associated with creating products and services. Organizational innovations are about the internal organization of an entity and its relations with the external environment. Last, but not least, marketing innovation is recognized as applying new marketing methods related to significant changes in the project of the product per se, its distribution, package, promotion or even pricing strategy. An indispensable aspect of innovations is their commercialization (necessary to classify actions as innovations). Thus, the following stages of developing innovations take place: its creation and commercialization (Carlino, Kerr 2014). In this research, the authors concentrate on various types of innovations: product and service innovations, innovations related to methods of production, innovative logistic, delivery or distribution systems, as well as innovative supporting activities. Undoubtedly, there are other issues related to innovations, that generally should not be underestimated, e.g. innovative activity such as scientific or technical research and other organizational actions leading to innovations, are crucial.

It is important why firms try to evolve innovations. Research and development $(\mathrm{R} \& \mathrm{D})$ may be very money and time-consuming, as well as relatively risky. Still, some firms, from start-ups to international corporations, do their best to develop revolutionary and breakthrough innovations. There is an altruistic explanation for such behaviour which is about creating products and services that are socially desirable because they make life easier. However, firms can be quite selfish in evolving innovations as they want to take the lead in the market competition and benefit from economic rent. Yet in order to do this, they have to put some assets on R\&D. They may rely on their own assets or obtain credit and loans from the financial sector. There is also a third way - to benefit from public support for innovative activity.

Thus firms could get some support from the state, but before commenting on different types of public support, it is relevant to highlight the reasons why public support for innovations is particularly well-worth of handling. The main reason why public support is a subject of broad debate, is that innovations 
in general, directly or indirectly, support the pace of economic growth of a state. Innovations could also serve as solutions to numerous social problems and be implemented in public policies.

The state is able to support firms in order to enhance creation of innovations in a number of ways. Broadly speaking, the state is responsible for the institutional surrounding of firms. Good formal and informal institutions may boost innovative activity. On the other hand, weak and suboptimal institutions can lead to economic stagnation and deter international proliferation of innovations. The state has instruments to develop an ecosystem and social capital friendly for innovative activity. The degree of openness of the economy or the condition of the financial sector are also important in the context of innovativeness. In the paper the authors focus above all on more direct ways of supporting innovative activity - subsidies or grants offered by the state.

The paper covers both the theoretical and empirical dimensions of the issue of public support for innovative firms, and analyses the determinants of creation of innovations in European firms with a particular interest in receiving public financial support. The main research question is whether direct financial public support for private entities to develop innovations is relevant and, if so, at what levels of support - regional, nationwide or international? The research aims to contribute to providing added value to the broad and current discussion over public policies regarding innovations.

\section{WHY DO FIRMS CARE ABOUT R\&D?}

A fundamental motive for developing innovations from the perspective of firms, is about expected economic rent. Firms do their best to create groundbreaking innovations in order to overtake their competition. Such a rent includes future streams of revenue due to sales of new or improved products. Firms may also improve their financial condition because of a reduction of costs of their business thanks to innovations they introduce. Innovative entities usually try, which is absolutely rational, to capture the highest accessible share of the market.

As the background for the analysis of the role of innovation in private business, one can recall Schumpeter's work. It turns out that apart from the purely revenue-side of motivations for starting an innovative activity, there is market competition. The innovator that manages to create a radical or revolutionary innovation (Freeman, Soete 1997), is inclined to monopolize the market, become the market leader and benefit from the economic rent just achieved (Schumpeter 1934). 
Firms could be even forced to evolve innovations. This occurs when the competition density is large (but does not imply the assumption about perfect competition). The more entities enter the market, the lower the price margin and revenue. A single firm has to introduce innovations in order to survive -in the market; in fact, it moves to another market, created by itself. Therefore the degree of market competition affects the proclivity for innovative activity. In addition, market competition should be considered (subject to data availability) with reference to the issue of the size of firms. Relatively small firms face a serious challenge with respect to achieving certain critical level of expenditure on R\&D necessary (generally) to develop innovations and introduce them to the market (Acs, Audretsch 1988). Another point is that in markets with strongly imperfect competition it is comparatively easier for market leaders to create innovations since they have incomparably more power over the market than in cases of perfect competition (Geroski 1990). It indicates another obstacle from the perspective of small entities, apart from the critical level of expenditures on R\&D.

It is interesting that market competition may have both a positive or negative character with respect to firms' innovativeness. What is crucial is that modern competition in a number of sectors is now even global. Technological change can be taken as gradually evolving, which is commonly assumed in economic papers. The degree of the factors' productivity is heterogeneous within the sector. Aghion et al. (2005) assume also that production costs are dependent on expenditure on innovations (R\&D) from the past. Then, in order to catch up with the market technological leader, it is necessary to make investments in R\&D.

Studies reveal that when the level of competition is low, an increase in competition works as an incentive for innovative activity (Gilbert 2006; Hovenkamp 2012; Tang 2006). Such a phenomenon is observed, because as the level of competition rises, firms' expectations about economic rent from being the leader, are also raised. This is called the escape-competition effect, and it is stronger in sectors characterized by low degree of technological differentiation, because it is possible to catch up with the market leader. In sectors with a high degree of technological differentiation it is necessary to narrow the technological distance between a firm and the leader.

The negative effects of market competition should not be neglected. In the long-run, intense market competition leads to some sectoral and national structural changes in the economy. When firms are doing their best to develop their technological advantage, the degree of technological differentiation grows. Then, in a larger number of sectors, the technological leaders establish their market dominance. As a consequence, aspiring firms become convinced 
that they are not able to catch up with the leaders and refrain from investing in innovations. Overall, the level of private investment in innovations in the economy is diminishing. This situation is unfavourable in terms of the number of revolutionary innovations.

As already mentioned, global competition is present in several sectors. Thus, firms have to take into account not only their local competitors, but also global ones. Recent research proves that the distance from the global technological frontier matters. By adapting the above-mentioned considerations to an open economy, it appears that rational firms would decide to invest in $\mathrm{R} \& \mathrm{D}$ only if they are close to the global technological frontier (Aghion et al. 2009; Klinger, Lederman 2006, Mytelka 2000).

Innovations are a sort of valuable assets of firms, because they are identified as 'non-rivalrous' (see the next section of the paper). A common feature of non-rivalrous ideas is the appropriability of rents. Usually R\&D is recognized as money and time-consuming. Thus, a firm that is considering a decision whether to invest in $\mathrm{R} \& \mathrm{D}$, compares estimated revenues (monopolistic rent) with costs (including different sorts of risk). Apart from this approach, it is crucial that not only the innovator may benefit from an innovation. Innovations may also affect social welfare (Mansfield et al. 1977). Moreover, because of knowledge and technology spillovers (diffusion of innovations), the competition gains additional revenues after adapting an innovation (Keller 2004; Liu, Buck 2007; Botazzi, Peri 2003).

From a general macroeconomic perspective, a significant factor that determines the scope and duration of monopolistic rent is intellectual property protection. Studies show that the relationship between the strength of intellectual property protection and the innovativeness of economies is reverse U-shaped (Furukawa 2010). Thus, too weak or too strong intellectual property protection affects innovativeness negatively. The optimal setting stands somewhere between and is related to a particular sector of economy. However, the relationship between intellectual property rights and economic development is proved to be significant and U-shaped (Chen, Puttitanun 2005).

Strong intellectual property protection leads to a higher number of monopolized sectors in the economy and results in a slower pace of production (Furukawa 2010). Since the scale of production diminishes as a consequence of monopoly pricing, the experience accumulation runs down with the strong protection of intellectual property (Furukawa 2007). Therefore the rate of productivity dynamics also diminishes in the final goods sector and the demand for semi-finished products declines. In such terms, strong intellectual property rights do not enhance economic growth. This phenomenon leads to fewer incentives for starting innovative activity within firms. Too strong 
intellectual property protection results in a situation unfavourable for sequential and complementary innovations (Bessen, Maskin 2009). Innovations do not exist in a vacuum - they rely on previous breakthroughs, so a whole ecosystem of innovations is highly desired. Hence a very strong intellectual property protection has more disadvantages than a setting without any kind of intellectual property protection at all. The main reason is limiting real incentives for commercial innovations and knowledge diffusion (Murray, Stern 2007).

On the one hand, from a firm's perspective, weak intellectual property protection could be perceived as a risk factor for innovators, because the period of the expected monopolistic rent will be shortened. However, this would also bring some market benefits, owing to the quicker diffusion of innovations. Yet it should be remembered that in such circumstances innovators have fewer incentives to generate innovations. On the other hand, stronger intellectual property protection is favourable to innovators, as long as they account for a long period of monopolistic rent.

Naturally, intellectual property protection may be a subject of disputes. Owners of patents or other forms of intellectual protection property may undertake actions to protect their monopolistic rents (Boldrin, Levine 2004; Boldrin, Levine 2009). The most common forms are lobbying, rent-seeking or court disputes. This issue is related to the transaction costs of business activity. Studies prove that the private protection of intellectual property with reference to innovativeness of the economy is also reverse U-shaped (Davis, Sener 2012). Therefore the interpretation could be that slight private protection of intellectual property serves as a provision for a monopolistic rent and enhances innovativeness in the economy. However too much private protection leads to lower levels of innovativeness (which is de facto blocked in the context of sequential innovations) and assets wasted due to the transaction costs of business.

Last but not least, the optimal level of intellectual property protection varies across different types of economies. It is suggested that the level should be relatively low in developing states, where innovations are rather adaptive and imitative (Kim et al. 2012). In developing countries, firms typically aim at introducing innovations in their national scope, as those innovations already exist abroad. This occurs since entities in poor and developing countries usually have less financial and human capital than those in developed countries, so it is harder for them to generate global breakthrough innovations. It seems an optimal strategy to incorporate external innovations rather than 're-invent the wheel'. Stronger intellectual property protection, in turn, should be applied instead to well-developed economies that have globally competitive entities 
(Thompson, Rushing 1999; Akiyama, Furukawa 2009). This is because of the huge risk of having the knowledge behind the innovation copied without any legal sanctions and costs of entry incurred by the real innovator.

\section{WHY SHOULD THE GOVERNMENT CARE ABOUT PRIVATE R\&D?}

This section describes the reasons for government's interest in the issue of innovations, while the next part of the paper deals with the means of public support for innovative firms. The main reason why governments should do their best to encompass innovativeness in the economy is the impact of innovativeness on economic growth. The theory of endogenous economic growth based on R\&D is recognized as one of the crucial spheres of modern macroeconomics (Romer 1990; Aghion, Howitt 1992, Verspagen 1992, Solow 1994). In particular, the impact of endogenous innovations on economic growth in the long-run is investigated as one of the key issues (Grossman, Helpman 1994).

Empirical research regarding funds for R\&D with respect to overall national expenditure on $\mathrm{R} \& \mathrm{D}$, firms' expenditure, as well as governmental support, reveal the significant and positive impact of expenditure on R\&D on economic growth (Bassanini et al. 2001), but only with reference to overall national funds and commercial ones (Bouis et al. 2011). Governmental spending on innovations is rather uncertain and may have a negative impact on economic growth as well. Public support may even crowd out firm-financed R\&D spending dollar for dollar (Wallsten 2000). However, such a public spending on innovations could be successful if properly targeted (Martin, Scott 2000). Another popular justification for the implementation of public policies supporting innovations, is related to notions of market failure (Dogdson et al. 2011).

It is also relevant that expenditure of firms and governments has different channels of impact on innovativeness. Firms' expenditure on R\&D is usually devoted to practical products or process innovations and concentrated on their market implementation. Government support, on the other hand, is more dedicated to basic and fundamental research. Sometimes fundamental research has to be developed significantly in order to think about any kind of commercialization (Bassanini et al. 2001). It may be said that governmental support for innovations is more focused on long-term effects, compared to private concerns (Bassanini et al. 2001, Audretsch 2004).

Different measures and standards are analyzed in order to check the impact of innovativeness on the economy (economic growth). One of the most 
common is the number of patents or rather the rate of growth of the number of declared patents. The impact of international patents on economic growth is positive, regardless of the different specifications of the determinants of economic growth (Fagerberg 1987). This effect varies depending on the type of economy. A significant and positive impact is observed in low and highincome countries, and not in middle-income countries (Falvey et al. 2006). However, the impact of intellectual property rights on economic growth is indirect and based on stimulating the accumulation of factor inputs like R\&D or physical capital (Park, Ginarte 1997). Countries with strong patent protection are confirmed to invest more in R\&D (Varsakelis 2001).

Other measures of the impact of the innovativeness on the economy are those of human capital (e.g. the Innovation Union Scoreboard or the Global Innovation Index). Analyses of selected types of human capital show that the average number of years of schooling of people aged 25-64 and the ratio of higher education alumni in the population have a positive impact on economic growth (Bassanini et al. 2001; Bouis et al. 2011). However, it is remarkable that the number of years of schooling does not say anything about the quality of education received. On the other hand, this factor has a positive influence on total factor productivity, which in turn, leads to higher economic growth (Bouis et al. 2011). Moreover, human capital could be increased within firms, e.g. by attending professional courses or just by gaining experience (Blundell et al. 1999; Baldwin, Johnson 1996). Such actions raise the human capital of employees and lead to increase in the number of innovations and to higher economic growth (Hatch, Dyer 2004).

Overall, in the majority of economic research, innovations seem to play a significant and positive role for supporting economic growth. Obviously, the results of particular research are dependent on the sets of factors included in the model and econometric methodology undertaken. There are also differences related to measures, indexes of innovations or their proxies.

Innovations have different features comparing to another factors of production, such as human capital or physical capital. An innovation that may take a form of a new technology can be classified as an idea and is "nonrivalrous'. A non-rivalrous idea, in turn, is a source of organizational development, because of positive returns to scale. One of the key features of innovations is knowledge creation and dissemination(Fischer 2001). What is special about technology is that it may be employed in a number of entities at the same time. Thus a firm that creates an innovation has to bear the costs of its development, but there are no costs associated with its usage (marginal costs of using a technology). This assumption and feature of innovations results in positive returns to scale that could lead to long-term economic growth (Romer 1990; Breschi, Lissoni 2001). 
However, in order to make a non-rivalrous idea (innovation), a component of high total factor productivity and economic growth, the relationship between expenditures on R\&D in the economy and the pace of technology development have to be strong enough. In countries close to the global technological frontier, the more investment in $\mathrm{R} \& \mathrm{D}$, the higher total factor productivity, and the economy grows in the next stage (Grossman, Helpman 1991). However, the relationship between expenditure on R\&D and economic growth is ambiguous (Jones 1995; Bilbao-Osorio, Rodriguez-Pose 2004; Madsen 2008). A positive association between industry R\&D expenditures and economic growth is observed more in developed countries like G-7 (Sylwester 2001). The aggregate rate of R\&D in the economy is also compared with the optimal rate, that appears to be the same for all preferences in a broad context (Stokey 1995). Studies reveal that a better approach to the relationship between expenditures on R\&D and economic growth, is the rate of intensity of investments in R\&D measured in relation to GDP (Ha, Howitt 2007). In such models the intensity of expenditures on R\&D affects positively the total factor productivity in the long run and leads to long-term economic growth. The R\&D spillovers are another element that may affect economic growth in some circumstances (Griliches 1992).

\section{STRATEGIES OF PUBLIC SUPPORT FOR INNOVATION}

When investigating macroeconomic characteristics that affect innovativeness, the level of development of financial sector plays an important role, because banks grant credits and loans for private firms in order to run $R \& D$, as well as equity markets which provide sources of financing (Bouis et al. 2011; Hsu et al. 2014). Industries, which are relatively more dependent on external financing and are high-tech intensive, are much more developed in countries with stronger equity markets (Hsu et al. 2014). Better developed financial sectors in general affect positively the pace of economic growth. One of the aspects of financial institutions' activity is supporting innovations. This could be linked with the issue of the role of the state - the state is able to determine, to some extent, the institutional environment of financial sectors (by regulations and active policies). In any case, the impact of financial sector on the economy is ambiguous, especially in the setting of the recent global financial crisis (Cecchetti, Kharroubi 2015; Levine 1997).

The openness of the economy is the next factor which determines the evolvement of innovations. The degree of openness of the economy may be approximated by export intensiveness or import penetration, share of exports and imports in GDP, or other common openness indexes (Bouis et al. 2011; 
Bessanini et al. 2001; Laursen, Salter 2005; Almeida, Fernandes 2008). Empirical analyses lead to the conclusion that the openness of the economy results in faster economic growth in the short and medium term, but this impact is not always strong (Harrison 1996). The key to this positive impact could lie in international investments undertaken in the country and the volume of trade (Edwards 1998).

The state is also in charge of regulations shaping institutional frames of business activity; some of the most common are product market regulation or employment market legislation. Bouis et al. (2011) stress and prove that countries with rigorous product market regulations and employment protection legislation are characterized by lower total factor productivity, which in turn, leads to slower economic growth.

Regulations created by the state serve as the basis for intellectual property protection. Intellectual property protection has an impact on the total factor productivity (Bouis et al. 2011). Nevertheless, the issue of the importance of intellectual property protection for economic growth is an underexploited area, and non-linear relations between intellectual property protection measures and total factor productivity have to be empirically tested.

The main framework policies that shape the regulatory environment for developing innovations include tax policy, labour market policy and regulations for the product market. The state has a selection of instruments that can be used in order to capture assets created by innovative and productive firms and to be transferred there from less productive entities. Such a policy is considered as more effective than creating a range of subsidies for innovators (Acemoglu et al. 2013). However, sometimes government support is expected (Gonzales et al. 2005). As a general conclusion from the literature survey it may be stated that institutional barriers for innovative activity should be reduced and this will have better results than active public policies for supporting innovative entities (Andrews et al. 2012).

Such barriers are, among others, high market entrance costs or costs of bankruptcy (Klapper et al. 2006; Andrews et al. 2014). This is particularly significant in modern branches of business and industries. Barriers usually have a differential influence on the various types of innovation (Guijarro et al. 2009; D'Este et al. 2012). The literature on the topic proposes two key kinds of barriers to innovation - the revealed barriers and deterring ones (D'Este et al. 2012). Revealed barriers reflect the degree of difficulty of the innovation process and the learning experience dependent on the firm's engagement in processing innovations. Deterring barriers, in turn, refer to obstacles that prevent firms from committing to innovations. The relationship between the assessment of the barriers and engagement in innovation activities is 
characterized by a non-linear relationship, indicating the presence of both deterring and revealed effects (D'Este et al. 2012). Although the obstacles to innovations are not equally distributed among entities, there are some typical sets of barriers depending on the age, size, type of industry, and the innovativeness of the firm (Pihkala, Ylinenpaa, Vesalainen 2002). Standard factors causing innovation barriers include: employment policy, financing means, legislation, competence and information, as well as external support.

Tax allowances are confirmed to affect positively the level of funds supporting commercial R\&D (Warwick, Nolan 2014; Mansfield, Switzer 1985; Mansfield 1986). However, conclusions regarding the relevance of tax regulation in this context are ambiguous and depend on the scope and subject of research (OECD 2010). It is said that in the context of economic crises or downturns, tax policies should keep on providing efficient incentives to fostering innovation (Palazzi 2011).

Labour market formal institutions are important from the perspective of innovators, because they determine the proportion of profit division between the investor and employees and the costs of labour (Cingano et al. 2010; SaintPaul 2002). In cases of strong employment protection legislation, the bargaining power of employees is relatively high, which is essential when the hold-up problem occurs (after the firm introduces an innovation). Thus the monopolistic rent that the entrepreneur desires to achieve, becomes lower. It is also proved empirically that more stringent dismissal laws enhance innovation, mainly in innovation-intensive industries. However, other labour laws do not (Acharya et al. 2013).

Too strong rights of creditors can discourage entrepreneurs from investing in innovations. In such circumstances the risk of innovative commercial activity is very high because the innovator may face very harsh obligations due to potential insolvency or bankruptcy (Acharya, Subramanian 2009).

From a general perspective, the stability of regulations and the predictability of the execution of legal rules is important for developing innovations (Nunn 2007). It also attracts investors from abroad and affects positively the diffusion of innovations. An effective legal system is not only a credible commitment for a state, but a respected system of legislature helps in the pursuance of business obligations (Andrews et al. 2015).

Innovations could be also a result of common actions and collective learning, social capital and strong interactions between the entities present in the market (Vinnova 2014; Landry et al. 2002). Accumulation of knowledge, human capital, organizational learning, as well as the creation of innovations, their diffusion and commercialization is often dependent on networking (Suorsa 2007; Lawson, Lorenz 1999; Melnikas 2008). Additionally, people 
tend to shape their perceptions of the value of an innovation through communication. Their perceptions, in turn, drive implementation that can be affected by some instrumental factors (Frank et al. 2004). Knowledge transfer and interactions between firms, academic institutions, clients, subcontractors and society are crucial (Jensen et al. 2007; Love, Roper 1999). Hence innovations are not only the result of individual efforts, but also of collective and network interrelationships. The state plays a significant role in providing such an interactive ecosystem, conductive to developing innovations. Social innovations, usable in several public policies, should not be neglected because they could also affect the functioning of innovative firms.

The state may develop active policies dedicated to enhancing innovativeness in the economy. Active pro-innovation policies could be regarded as solutions to some structural problems and a way to popularize innovative commercial activity (Jaumotte, Pain 2005). Such policies may be concentrated on the practical involvement of the institutional surrounding of innovative activity, and the direct or indirect creation of ecosystems favourable to developing innovations. For instance, primarily the selected sectors or social goals may be supported. In particular, this can mean promoting the commercialization of ideas, co-operation between firms and the academic sector, and transferring funds for selected types of entities (for instance small and medium enterprises). One of the most crucial characteristics of this type of public support for firms is the coordination of institutions involved in the process (OECD 2014). Moreover, such systems of support have to be dynamic to adapt to the current needs, business trends and correct mistakes in funds allocation.

Studies stress that public policies devoted to the support of commercial innovations should be flexible and adjusted to the needs of firms of different types. Public grants, subsidies and other forms of accountable financial support have proven to be more appropriate to help bigger firms and corporations, e.g. because of their ability to handle administrative duties (European Commission 2014). Grants and subsidies may be a crucial help in developing innovations, but they usually cause bureaucratic responsibilities and generate transaction costs accompanying innovative activities which may be a serious barrier to small firms.

Legal regulations and other formal institutions are especially helpful for small and medium entities (European Commission 2014). The available sources confirm that the regulatory ease of doing business, tax allowances and other institutional (formal) issues are more relevant for small and medium firms than for larger ones. This occurs because of the better administrative and legal capabilities of corporations to adapt to an institutional environment. Additionally, global firms tend to be located in countries with the most 
attractive regulations with respect to their domain. Another aspect of public support is its accountability. The effects of grants and subsidies are usually easier to measure than legal systems or non-refundable (and subjective) donations, which is crucial in designing further public policies. This is the key argument, apart from data availability, why the empirical part of this paper considers public financial support - grants, subsidies, tax credits or deductions, subsidized loans and loan guarantees.

The literature review provided in this paper is concentrated primarily on the internal instruments of supporting the innovativeness of the economy. Naturally, there are also other significant means that refer to international relations, political stability, international trade or international agreements that may play a role in policies devoted to innovativeness (Felbermayr, Yalcin 2013).

\section{THE MODEL}

The next sections of the paper concern an empirical verification of the above-mentioned research question about the impact of different means of public financial support on the innovativeness of an enterprise. The scope of the authors' interest covers public funding for product or process innovation coming from three different sources, i.e. local or regional authorities, central government and the European Union. Each of these types differs in terms of accessibility and flexibility of support, therefore it seems essential to analyze them separately. The aim is to test whether receiving public funding boosts the innovativeness of the enterprise. The database used in this study consists in the Community Innovation Survey (CIS) enriched by the data published by the World Bank and Kaufmann et al. (2016).

The CIS is a survey of innovation activity in enterprises. Its uniqueness is associated with the fact that it includes detailed information concerning different types of public support and innovations conducted in a variety of European countries. It is conducted in waves with the frequency of two years by the EU member states, Norway and Iceland. Participation in the survey is voluntary for a country, therefore the data are not available for all of the EU member states. The study used the CIS 2012 wave containing the data collected in 2010 and 2012. The database after deleting observations with missing dependent variables, comprises observations for 40,556 enterprises from 8 countries $^{1}$. The considerable size of the database ensures the representativeness

${ }^{1}$ Bulgaria, Germany, Estonia, Spain, Hungary, Portugal, Romania, Slovenia. 
of the sample and increases the credibility of the obtained empirical results. Table 1 presents the number of firms that received public funding for the development of innovativeness by countries and types of funding.

Table 1

Public funding in European enterprises

\begin{tabular}{l|r|r|r|r}
\hline & $\begin{array}{c}\text { Number of observations } \\
\text { in the sample }\end{array}$ & \multicolumn{1}{|c|}{$\begin{array}{c}\text { Government } \\
\text { funding }\end{array}$} & $\begin{array}{c}\text { Local } \\
\text { funding }\end{array}$ & EU funding \\
\hline Bulgaria & 2409 & 266 & 37 & 347 \\
\hline Germany & 3660 & 649 & 295 & 230 \\
\hline Estonia & 113 & 51 & 6 & 113 \\
\hline Spain & 32080 & 2975 & 2295 & 720 \\
\hline Hungary & 1229 & 296 & 27 & 369 \\
\hline Portugal & 442 & 270 & 45 & 442 \\
\hline Romania & 534 & 70 & 23 & 98 \\
\hline Slovenia & 100 & 76 & 5 & 100 \\
\hline
\end{tabular}

Source: CIS 2012, own elaboration.

The majority of enterprises included in the dataset comes from three countries, i.e. Spain, Germany and Bulgaria. What is more, in the sample there are present countries characterized by different levels of economic and social development and by different length of their membership in the EU. Such heterogeneity enables to draw general conclusions for the European Union as a whole.

The main goal of the empirical research is to test whether the public support obtained by enterprises from three different sources contributes to the firms' decision about their involvement in innovative activities and their success within this field. In this model the authors distinguish and use as dependent variables five different events, whose occurrence indicates that a given enterprise may be considered as an innovator:

- the enterprise introduced a new or significantly improved good to the market (variable inpdgd),

- the enterprise introduced a new or significantly improved service to the market (variable inpdsv),

- the enterprise introduced a new or significantly improved method of production to the market (variable inpspd);

- the enterprise introduced a new or significantly improved logistic, delivery or distribution system to the market (variable inpslg); 
- the enterprise introduced new or significantly improved supporting activities to the market (variable inpssu).

These innovation activities combine both product and process innovations. Such an enlargement of analysis to different types of innovations could enable checking whether public support may have a particular importance for a specific type of innovative activity. From the initial analysis it appears that there are huge differences with respect to the frequency of completed innovations. The most innovative firms that took part in the survey had Spain and Hungary as their country of residence, while the least innovative firms were from Bulgaria and Germany. The two most common innovative activities were the introduction of a new or significantly improved good, and the introduction of a new or significantly improved method of production. The smallest percentage of firms were involved in the introduction of a new or significantly improved logistic, delivery or distribution system to the market.

The CIS survey offers data concerning four types of public funding provided for innovators: public funding from local or regional authorities (funloc), public funding from central government (fungmt) and public funding from the EU (funeu). The reception of such public funds should positively contribute to the probability that a firm would succeed in product or process innovations. Figures 1 to 3 present the percentage of firms that received public funding coming from the above-mentioned sources. According to the data, the most common type of public funding in the majority of countries is EU

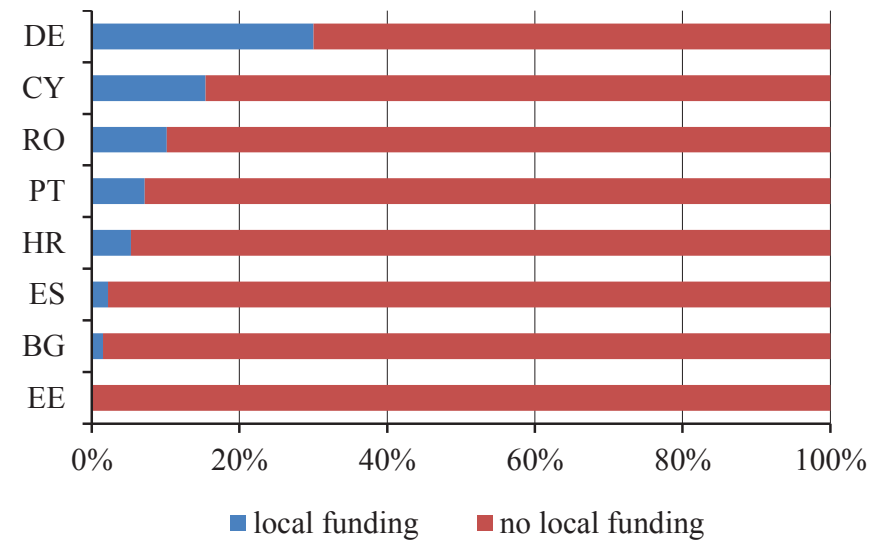

Fig. 1. The percentage of enterprises that received public funding from local or regional authorities in 2012 by country.

Source: own work on the basis of CIS 2012. 


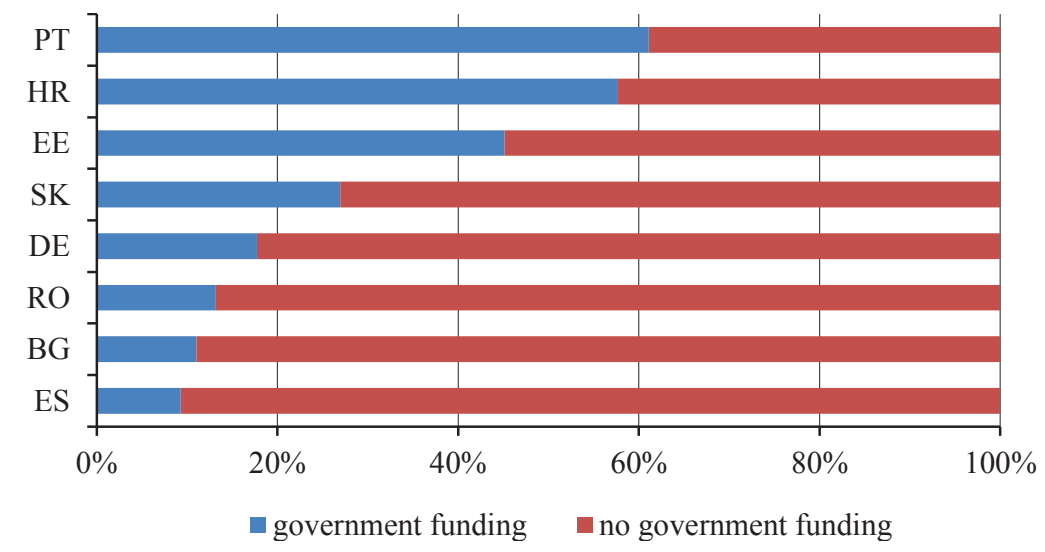

Fig. 2. The percentage of enterprises that received public funding from central government authorities in 2012 by country

Source: own work on the basis of CIS 2012.

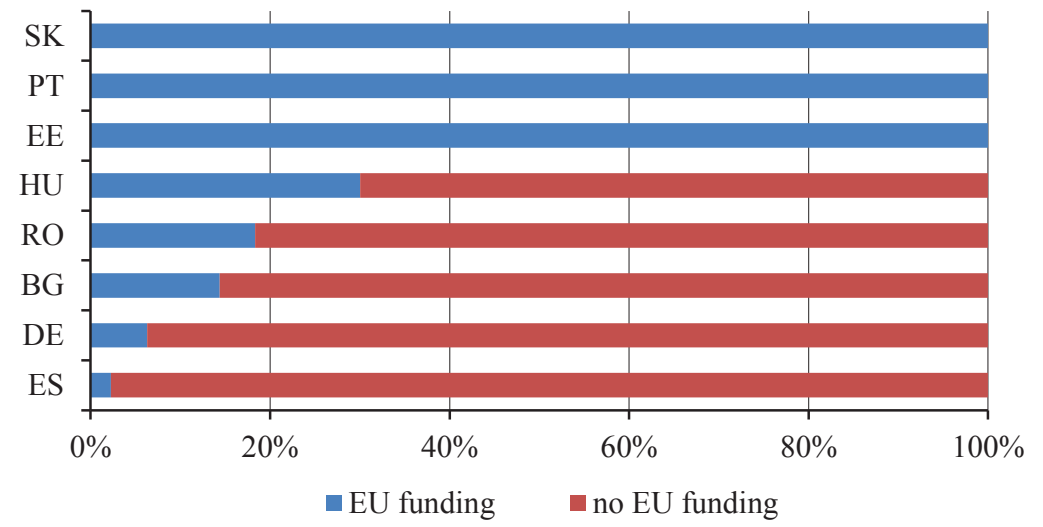

Fig. 3. The percentage of enterprises that received public funding from the EU in 2012 by country

Source: own work on the basis of CIS 2012.

funding, while the least common is local funding. It is worth mentioning that Spanish firms which are characterised by a comparatively high level of innovative activities, definitely less frequently received public funding in comparison to entities from other countries. 


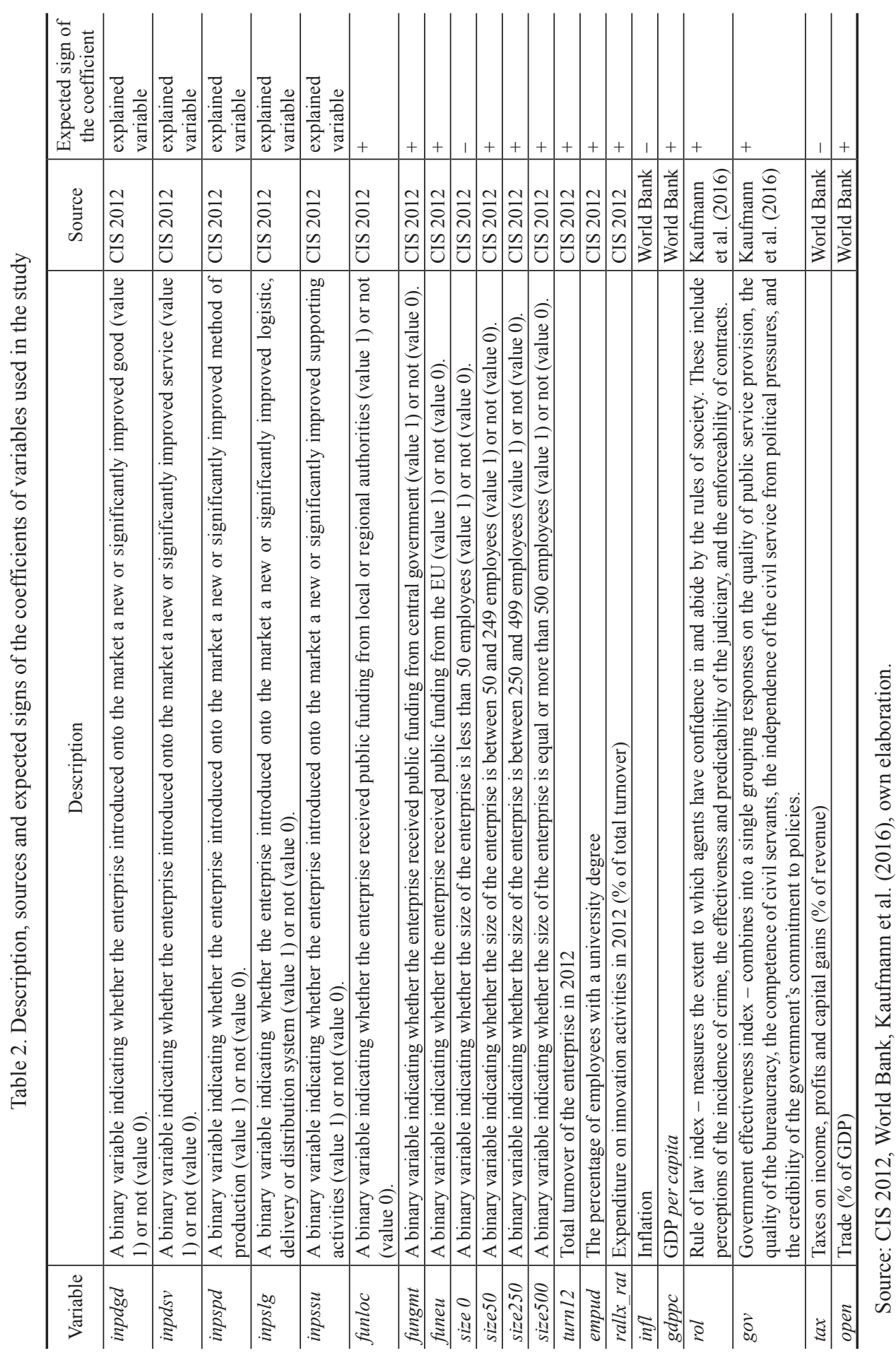


In the model specification there is also a set of control variables related to firms' characteristics and economic conditions in the resident country of the enterprise. Table 2 presents a description of the variables used in the study. More detailed descriptive statistics, including the correlations between variables are included in the Appendix, in Tables 6,7 and 8 .

The independent variables may be divided into two groups, i.e. firm-level characteristics and country-level characteristics. Below is presented the list of firm-level variables and ancillary hypotheses to be tested by the model:

- the size of the enterprise expressed by the number of employees (less than 50 size 0 , between 50 and 249 size 50, 250-499 size250, more than 500 size 500). The larger the firm is, the higher should be the probability that it will engage in innovations,

- the total turnover of the enterprise in 2010. The higher the turnover, the higher should be the probability of innovation as the firm has more money to spend on $R \& D$ (the logic is that higher turnover creates more space [in absolute terms] for expenditure on innovation activities), and the percentage of employees with a university degree (empud). A high percentage of welleducated employees indicates a high level of human capital in the firm and therefore should encourage the occurrence of innovation activities in the firm(this is a general impression based on the literature review and made due to data availability; specific regularities depend on particular sectorsin high-tech industries a vital role is played by education in natural and sciences),

- the total expenditure on innovation activities in 2012 (\% of total turnover, rallx_rat). Its occurrence should increase the probability of innovation.

Country-level characteristics are related to the economic and institutional conditions in the place of residence of the firm. The 'economic' variables are inflation (infl), trade as a percentage of GDP (open) and GDP per capita $(g d p p c)$, while the institutional ones concern the level of taxes on income, profits and capital gains (tax), the state of the rule of law (rol) and the level of government's effectiveness (gov). In the course of this empirical research the authors aimed to test the following hypotheses related to the economic and institutional firm's environment:

- the better the economic condition of the country (i.e. the higher the level of GDP per capita and the lower the level of inflation), the higher the probability that firm engages in innovation activities;

- the more open the economy (what is envisaged as the higher share of trade in GDP), the higher the competition that the firm faces, therefore the probability of innovation activities should increase; 
- the higher the level of taxes on income, profits and capital gains, the higher the costs of business activities, which decreases the probability of a firm's engagement in innovation activities;

- the higher the quality of the institutional environment in which the firm operates (i.e. the higher the values of rule of law and government effectiveness indices), the higher the probability that it will engage in innovation activities.

The econometric methodology used for estimation is twofold - a crosssection probit model and a bivariate probit model (as a robustness check). The estimation was repeated five times - each time with a different dependent variable indicating the type of innovation event.

The general model specification is as follows:

$$
\begin{gathered}
\text { innovation }_{i}=\alpha_{i}+\text { funloc }_{i}+\text { fungmt }_{i}+\text { funeu }_{i}+\text { FirmCharacteristics }_{i}+ \\
\text { CountryCharacteristics } \\
+
\end{gathered}
$$

where innovation is one of the dependent variables (inpdgd, inpdsv, inpspd, inpslg, inpssu), FirmCharacteristics relates to all of the firm-level characteristics variables described above, CountryCharacteristics represents all of the country-level characteristics variables described above, $\alpha$ is constant and $\varepsilon$ is the error term.

Table 3 presents the preliminary results of the probit estimation.

The model results indicate the positive effects of local, government and EU public funding on all types of innovations. Therefore one may conclude that public policy, whose aim is to support enterprises by means of funding, should provide incentives for firms to engage successfully into innovative activities. What is more, coefficients estimated for the firm-level variables in general confirm the proposed hypotheses. The model results indicate that a larger size of the firm and a higher level of employees' education increase the probability of the occurrence of all types of innovations. The only results that do not fully confirm the hypotheses are those related to the firm's turnover and expenditures on innovation activities. The effect of a firm's turnover on innovation activities is significant, but equal almost to zero, while the impact of a firm's expenditures on innovation activities is insignificant. The probit outcomes suggest the significance of the economic and institutional firm environment for explaining the probability of innovation. The GDP per capita exerts a significant, yet negligible impact on the probability of innovation, while the increase of inflation contributes to its lowering. The openness of the economy appears to be a significant negative explanation of the probability of 
Table 3

The results of probit estimation

\begin{tabular}{|c|c|c|c|c|c|}
\hline & inpdgd & inpdsv & inpspd & Inpslg & inpssu \\
\hline \multirow[t]{2}{*}{ funloc } & $0.633^{*} * *$ & $0.447 * * *$ & $0.631^{* * *}$ & $0.344 * * *$ & $0.379 * * *$ \\
\hline & $(0.03)$ & $(0.03)$ & $(0.03)$ & $(0.04)$ & $(0.03)$ \\
\hline \multirow[t]{2}{*}{ fungmt } & $0.752 * * *$ & $0.422 * * *$ & $0.579 * * *$ & $0.305^{* * *}$ & $0.314 * * *$ \\
\hline & $(0.02)$ & $(0.02)$ & $(0.02)$ & $(0.03)$ & $(0.02)$ \\
\hline \multirow[t]{2}{*}{ funeu } & $0.104 * *$ & $0.133 * * *$ & $0.275^{* * *}$ & 0.014 & 0.052 \\
\hline & $(0.03)$ & $(0.04)$ & $(0.03)$ & $(0.04)$ & $(0.04)$ \\
\hline \multirow[t]{2}{*}{ rallx_rat } & 0.000 & -0.000 & 0.000 & -0.000 & 0.000 \\
\hline & $(0.00)$ & $(0.00)$ & $(0.00)$ & $(0.00)$ & $(0.00)$ \\
\hline \multirow[t]{2}{*}{ turn12 } & $0.000 * * *$ & $0.000^{*}$ & $0.000 * * *$ & $0.000 * * *$ & $0.000 * * *$ \\
\hline & $(0.00)$ & $(0.00)$ & $(0.00)$ & $(0.00)$ & $(0.00)$ \\
\hline \multirow[t]{2}{*}{ empud } & $0.078 * * *$ & $0.177 * * *$ & $0.046^{* * *}$ & $0.044 * * *$ & $0.118 * * *$ \\
\hline & $(0.00)$ & $(0.01)$ & $(0.00)$ & $(0.01)$ & $(0.00)$ \\
\hline \multirow[t]{2}{*}{ size 500} & $0.293 * * *$ & $0.517 * * *$ & $0.400 * * *$ & $0.687 * * *$ & $0.743 * * *$ \\
\hline & $(0.04)$ & $(0.04)$ & $(0.04)$ & $(0.04)$ & $(0.03)$ \\
\hline \multirow[t]{2}{*}{ size250 } & $0.243 * * *$ & $0.268 * * *$ & $0.377 * * *$ & $0.514 * * *$ & $0.563 * * *$ \\
\hline & $(0.03)$ & $(0.03)$ & $(0.03)$ & $(0.04)$ & $(0.03)$ \\
\hline \multirow[t]{2}{*}{ size50 } & $0.206^{* * *}$ & $0.087 * * *$ & $0.235 * * *$ & $0.256 * * *$ & $0.293 * * *$ \\
\hline & $(0.02)$ & $(0.02)$ & $(0.02)$ & $(0.02)$ & $(0.02)$ \\
\hline \multirow[t]{2}{*}{$g d p p c$} & $-0.000 * * *$ & $-0.000 * * *$ & $-0.000 * * *$ & $-0.000 * * *$ & $-0.000 * * *$ \\
\hline & $(0.00)$ & $(0.00)$ & $(0.00)$ & $(0.00)$ & $(0.00)$ \\
\hline \multirow[t]{2}{*}{ infl } & 0.073 & -0.017 & $-0.131 * *$ & -0.103 & 0.079 \\
\hline & $(0.05)$ & $(0.05)$ & $(0.05)$ & $(0.06)$ & $(0.05)$ \\
\hline \multirow[t]{2}{*}{ gov } & 0.353 & $0.701 * * *$ & $0.402 *$ & 0.272 & $1.529 * * *$ \\
\hline & $(0.20)$ & $(0.21)$ & $(0.19)$ & $(0.22)$ & $(0.20)$ \\
\hline \multirow[t]{2}{*}{$\mathrm{rol}$} & 0.183 & 0.390 & $1.136^{* * *}$ & $1.068 * * *$ & $0.623 * *$ \\
\hline & $(0.20)$ & $(0.21)$ & $(0.19)$ & $(0.23)$ & $(0.20)$ \\
\hline \multirow[t]{2}{*}{$\operatorname{tax}$} & $-0.072 * * *$ & $-0.057 * * *$ & $-0.046 * * *$ & $-0.073 * * *$ & $-0.071 * * *$ \\
\hline & $(0.01)$ & $(0.01)$ & $(0.01)$ & $(0.01)$ & $(0.01)$ \\
\hline \multirow[t]{2}{*}{ open } & $-0.007 * * *$ & $-0.008 * * *$ & -0.003 & $-0.009 * * *$ & $-0.017 * * *$ \\
\hline & $(0.00)$ & $(0.00)$ & $(0.00)$ & $(0.00)$ & $(0.00)$ \\
\hline \multirow[t]{2}{*}{ cons } & $1.484 * * *$ & $0.897 * * *$ & $1.293 * * *$ & $1.890 * * *$ & $2.497 * * *$ \\
\hline & $(0.25)$ & $(0.26)$ & $(0.25)$ & $(0.28)$ & \\
\hline $\begin{array}{l}\text { Number of } \\
\text { observations }\end{array}$ & 40530 & 40530 & 40530 & 40530 & 40530 \\
\hline LR chi2(10) & 6383.40 & 3942.79 & 4356.56 & 2002.64 & 3741.90 \\
\hline
\end{tabular}

Notes: Values of $z$ statistics in brackets. ${ }^{*}$ significant at $10 \%$ level, $* *$ significant at $5 \%$ level, *** significant at $1 \%$ level.

Source: own elaboration. 
innovation. Such a result does not correspond with the theoretical considerations presented above. One of the reasons for such a result may depend on the selected measure of the openness of the economy. In this case the measure may achieve much higher values for small open economies. Furthermore, the outcomes suggest the significant and negative impact of the corporate income tax rate on the occurrence of innovation activity. For certain kinds of innovation activities, government's efficiency and the rule of law are significant and positive determinants.

In order to check the robustness of the results, the authors propose an alternative specification accounting for the fact that investment in one kind of innovation decreases the cost of implementation of innovation of the other type and as a result may increase the probability of its appearance. Such a phenomenon is most likely to occur in cases of process innovation. The introduction of a new method of production, a distribution system or other supporting activities may go alongside and support the introduction the product innovation. Not accounting for this potential source of endogeneity may result in the bias of estimators. Therefore, in order to control for the unobserved heterogeneity, the authors estimated a different model - a bivariate probit model controlling for the potential interaction between process and product innovations. In the model there is included an additional binary variable (initps), also in line with the conclusions from the literature review, specific solely to the equation concerning different types of process innovation. It accounts for the fact of whether the enterprise developed the innovation by itself (value 1) or in cooperation with other institutions. Table 4 presents the results of a bivariate probit model accounting for the impact of the development of different types of process innovation on the introduction of a new or significantly improved good into the market.

The obtained results support the outcomes from the simple probit model, i.e. the model indicated that the reception of public funding by a firm increases the probability of occurrence of innovation. This conclusion holds for all types of public funding. Furthermore, the regression results provided support for the hypothesis that the introduction of process innovation increases the probability of the product innovation concerning the introduction onto the market of a new or significantly improved good.

The authors conducted an analogous type of analysis for the second type of product innovation i.e. for the introduction into the market of a new or significantly improved service (Table 5). The conclusions arising from these results are similar to those presented in Table 4. 
Table 4

The results of bivariate probit regression. The introduction into the market of a new or significantly improved good as a dependent variable

\begin{tabular}{|c|c|c|c|c|c|c|}
\hline & inpdgd & inpspd & inpdgd & inpslg & inpdgd & inpssu \\
\hline \multirow[t]{2}{*}{ inpspd } & $1.256^{* * *}$ & & & & & \\
\hline & $(0.08)$ & & & & & \\
\hline \multirow[t]{2}{*}{ initps } & & $1.860 * * *$ & & $1.315 * * *$ & & $1.363 * * *$ \\
\hline & & $(0.06)$ & & $(0.06)$ & & $(0.06)$ \\
\hline \multirow[t]{2}{*}{ fungmt } & $0.523 * * *$ & $0.406 * * *$ & $0.622 * * *$ & 0.036 & $0.640 * * *$ & -0.014 \\
\hline & $(0.04)$ & $(0.04)$ & $(0.04)$ & $(0.04)$ & $(0.04)$ & $(0.04)$ \\
\hline \multirow[t]{2}{*}{ funloc } & $0.194 * * *$ & 0.259 *** & $0.277 * * *$ & 0.030 & $0.299 * * *$ & -0.056 \\
\hline & $(0.04)$ & $(0.05)$ & $(0.04)$ & $(0.05)$ & $(0.04)$ & $(0.05)$ \\
\hline \multirow[t]{2}{*}{ funeu } & $0.147 * *$ & $0.299 * * *$ & $0.256 * * *$ & -0.042 & $0.256^{* * *}$ & -0.039 \\
\hline & $(0.05)$ & $(0.06)$ & $(0.05)$ & $(0.06)$ & $(0.05)$ & $(0.06)$ \\
\hline \multirow[t]{2}{*}{ rallx_rat } & 0.000 & -0.000 & 0.000 & -0.000 & 0.000 & 0.000 \\
\hline & $(0.00)$ & $(0.00)$ & $(0.00)$ & $(0.00)$ & $(0.00)$ & $(0.00)$ \\
\hline \multirow[t]{2}{*}{ turn12 } & 0.000 & 0.000 & 0.000 & $0.000 * * *$ & 0.000 & $0.000 * * *$ \\
\hline & $\begin{array}{l}(0.00) \\
\end{array}$ & $(0.00)$ & $(0.00)$ & $(0.00)$ & $(0.00)$ & $(0.00)$ \\
\hline \multirow[t]{2}{*}{ eтpud } & $0.033 * * *$ & $-0.048 * * *$ & $0.021 * *$ & -0.018 & -0.007 & $0.107 * * *$ \\
\hline & $(0.01)$ & $(0.01)$ & $(0.01)$ & $(0.01)$ & $(0.01)$ & $(0.01)$ \\
\hline \multirow[t]{2}{*}{ size 500} & $0.242 * * *$ & -0.118 & 0.065 & $0.481 * * *$ & 0.091 & $0.503 * * *$ \\
\hline & $(0.06)$ & $(0.06)$ & $(0.06)$ & $(0.06)$ & $(0.06)$ & $(0.06)$ \\
\hline \multirow[t]{2}{*}{ size250 } & $0.190 * * *$ & -0.022 & 0.087 & $0.308 * * *$ & $0.103^{*}$ & $0.331 * * *$ \\
\hline & $(0.05)$ & $(0.06)$ & $(0.05)$ & $(0.06)$ & $(0.05)$ & $(0.05)$ \\
\hline \multirow[t]{2}{*}{ size 50} & $0.138 * * *$ & 0.024 & $0.117 * * *$ & $0.112 * *$ & $0.111 * * *$ & $0.163 * * *$ \\
\hline & $(0.03)$ & $(0.03)$ & $(0.03)$ & $(0.03)$ & $(0.03)$ & $(0.03)$ \\
\hline \multirow[t]{2}{*}{$g d p p c$} & -0.000 & $-0.000^{* * *}$ & 0.000 & $-0.000 * * *$ & 0.000 & $-0.000 * * *$ \\
\hline & $(0.00)$ & $(0.00)$ & $(0.00)$ & $(0.00)$ & $(0.00)$ & $(0.00)$ \\
\hline \multirow[t]{2}{*}{ infl } & $0.257 * *$ & -0.032 & $0.249 * *$ & -0.049 & $0.203^{*}$ & 0.133 \\
\hline & $(0.09)$ & $(0.12)$ & $(0.09)$ & $(0.10)$ & $(0.09)$ & $(0.09)$ \\
\hline \multirow[t]{2}{*}{ gov } & $0.769^{*}$ & 0.295 & 0.349 & $1.065^{* *}$ & 0.220 & $2.149 * * *$ \\
\hline & $(0.32)$ & $(0.39)$ & $(0.32)$ & $(0.34)$ & $(0.32)$ & $(0.32)$ \\
\hline \multirow[t]{2}{*}{$\mathrm{rol}$} & -0.681 & 0.800 & $0.727^{*}$ & 0.619 & $0.734^{*}$ & $0.783^{*}$ \\
\hline & $(0.35)$ & $(0.45)$ & $(0.35)$ & $(0.38)$ & $(0.35)$ & $(0.35)$ \\
\hline \multirow[t]{2}{*}{$\operatorname{tax} r$} & $-0.038 * * *$ & $-0.027 *$ & 0.008 & $-0.081 * * *$ & -0.003 & -0.070 *** \\
\hline & $(0.01)$ & $(0.01)$ & $(0.01)$ & $(0.01)$ & $(0.01)$ & $(0.01)$ \\
\hline \multirow[t]{2}{*}{ open } & $-0.009 * *$ & -0.004 & -0.003 & $-0.013 * * *$ & -0.002 & $-0.023 * * *$ \\
\hline & $(0.00)$ & $(0.00)$ & $(0.00)$ & $(0.00)$ & $(0.00)$ & $(0.00)$ \\
\hline \multirow[t]{2}{*}{ inpslg } & & & $1.107 * * *$ & & & \\
\hline & & & $(0.09)$ & & & \\
\hline \multirow[t]{2}{*}{ inpssu } & & & & & $0.684 * * *$ & \\
\hline & & & & & $(0.08)$ & \\
\hline \multirow[t]{2}{*}{ cons } & -0.551 & 0.255 & $-1.402 * * *$ & $1.725 * * *$ & $-1.053 * *$ & $2.339 * * *$ \\
\hline & $(0.34)$ & $(0.42)$ & $(0.35)$ & $(0.36)$ & $(0.35)$ & $(0.36)$ \\
\hline $\begin{array}{l}\text { Number of } \\
\text { observations }\end{array}$ & \multicolumn{2}{|c|}{10240} & \multicolumn{2}{|c|}{10240} & \multicolumn{2}{|c|}{10240} \\
\hline \multirow[t]{2}{*}{ rho } & & & & & & \\
\hline & & & & & & \\
\hline
\end{tabular}

Notes: Values of $z$ statistics in brackets. * significant at $10 \%$ level, ${ }^{* *}$ significant at $5 \%$ level, $* * *$ significant at $1 \%$ level.

Source: own elaboration. 
Table 5

The results of bivariate probit regression. The introduction into the market of a new or significantly improved service as dependent variable

\begin{tabular}{|c|c|c|c|c|c|c|}
\hline & inpdsv & inpspd & inpdsv & inpslg & inpdsv & inpssu \\
\hline \multirow[t]{2}{*}{ inpspd } & $0.627 * * *$ & & & & & \\
\hline & $(0.08)$ & & & & & \\
\hline \multirow[t]{2}{*}{ initps } & & $1.867 * * *$ & & $1.220 * * *$ & & $1.265^{* * *}$ \\
\hline & & $(0.06)$ & & $(0.06)$ & & $(0.06)$ \\
\hline \multirow[t]{2}{*}{ fungmt } & $0.182 * * *$ & $0.413^{* * *}$ & $0.245^{* * *}$ & 0.075 & $0.261 * * *$ & 0.017 \\
\hline & $(0.04)$ & $(0.04)$ & $(0.04)$ & $(0.04)$ & $(0.04)$ & $(0.04)$ \\
\hline \multirow[t]{2}{*}{ funloc } & $0.100 *$ & $0.255^{* * *}$ & $0.145^{* *}$ & 0.037 & 0.170 *** & -0.045 \\
\hline & $(0.05)$ & $(0.05)$ & $(0.05)$ & $(0.05)$ & $(0.05)$ & $(0.04)$ \\
\hline \multirow[t]{2}{*}{ funeu } & 0.043 & $0.295^{* * * *}$ & 0.108 & -0.042 & 0.104 & -0.030 \\
\hline & $(0.06)$ & $(0.06)$ & $(0.05)$ & $(0.06)$ & $(0.06)$ & $(0.06)$ \\
\hline \multirow[t]{2}{*}{ rallx_rat } & -0.000 & -0.000 & -0.000 & -0.000 & -0.000 & 0.000 \\
\hline & $(0.00)$ & $(0.00)$ & $(0.00)$ & $(0.00)$ & $(0.00)$ & $(0.00)$ \\
\hline \multirow[t]{2}{*}{ turn12 } & 0.000 & $0.000 *$ & -0.000 & $0.000 * * *$ & -0.000 & $0.000^{* * * *}$ \\
\hline & $(0.00)$ & $(0.00)$ & $(0.00)$ & $(0.00)$ & $(0.00)$ & $(0.00)$ \\
\hline \multirow[t]{2}{*}{ empud } & $0.172 * * *$ & $-0.047 * * *$ & $0.170^{* * *}$ & -0.013 & $0.128^{* * *}$ & $0.112^{* * *}$ \\
\hline & $(0.01)$ & $(0.01)$ & $(0.01)$ & $(0.01)$ & $(0.01)$ & $(0.01)$ \\
\hline \multirow[t]{2}{*}{ size500 } & $0.250 * * *$ & -0.114 & 0.090 & $0.488 * * *$ & 0.048 & $0.512 * * *$ \\
\hline & $(0.06)$ & $(0.06)$ & $(0.06)$ & $(0.06)$ & $(0.06)$ & $(0.06)$ \\
\hline \multirow[t]{2}{*}{ size250 } & 0.032 & -0.011 & -0.068 & $0.319 * * *$ & -0.089 & $0.346^{* * *}$ \\
\hline & $(0.05)$ & $(0.06)$ & $(0.06)$ & $(0.06)$ & $(0.06)$ & $(0.05)$ \\
\hline \multirow[t]{2}{*}{ size50 } & $-0.070^{*}$ & 0.025 & $-0.093^{* *}$ & $0.116^{* * *}$ & $-0.120^{* * *}$ & $0.166^{* * *}$ \\
\hline & $(0.03)$ & $(0.03)$ & $(0.03)$ & $(0.03)$ & $(0.03)$ & $(0.03)$ \\
\hline \multirow[t]{2}{*}{$g d p p c$} & $-0.000 * * *$ & $-0.000^{* * *}$ & $-0.000^{* * *}$ & $-0.000 * * *$ & $-0.000^{*}$ & $-0.000^{* * *}$ \\
\hline & $(0.00)$ & $(0.00)$ & $(0.00)$ & $(0.00)$ & $(0.00)$ & $(0.00)$ \\
\hline \multirow[t]{2}{*}{ infl } & -0.142 & -0.017 & -0.134 & -0.044 & $-0.201 *$ & 0.137 \\
\hline & $(0.09)$ & $(0.11)$ & $(0.09)$ & $(0.10)$ & $(0.10)$ & $(0.09)$ \\
\hline \multirow[t]{2}{*}{ gov } & $0.724 *$ & 0.352 & 0.402 & $1.067 * *$ & 0.035 & 2.131 *** \\
\hline & $(0.33)$ & $(0.39)$ & $(0.34)$ & $(0.34)$ & $(0.34)$ & $(0.32)$ \\
\hline \multirow[t]{2}{*}{ rol } & 0.344 & 0.739 & 0.294 & 0.528 & 0.282 & 0.694 \\
\hline & $(0.36)$ & $(0.44)$ & $(0.36)$ & $(0.38)$ & $(0.36)$ & $(0.35)$ \\
\hline \multirow[t]{2}{*}{$\operatorname{tax} r$} & -0.014 & $-0.029^{*}$ & 0.011 & $-0.074 * * *$ & 0.001 & $-0.062 * * *$ \\
\hline & $(0.01)$ & $(0.01)$ & $(0.01)$ & $(0.01)$ & $(0.01)$ & $(0.01)$ \\
\hline \multirow[t]{2}{*}{ open } & -0.003 & -0.005 & 0.001 & $-0.013 * * *$ & 0.004 & $-0.023 * * *$ \\
\hline & $(0.00)$ & $(0.00)$ & $(0.00)$ & $(0.00)$ & $(0.00)$ & $(0.00)$ \\
\hline \multirow[t]{2}{*}{ inpslg } & & & $1.057 * * *$ & & & \\
\hline & & & $(0.13)$ & & & \\
\hline \multirow[t]{2}{*}{ inpssu } & & & & & $1.006^{* * *}$ & \\
\hline & & & & & $(0.10)$ & \\
\hline \multirow[t]{2}{*}{ cons } & -0.074 & 0.279 & $-0.958^{* *}$ & $1.618 * * *$ & $-0.983^{* *}$ & $2.193^{* * *}$ \\
\hline & $(0.34)$ & $(0.41)$ & $(0.37)$ & $(0.36)$ & $(0.36)$ & $(0.36)$ \\
\hline $\begin{array}{l}\text { Number of } \\
\text { observations }\end{array}$ & \multicolumn{2}{|c|}{10240} & \multicolumn{2}{|c|}{10240} & \multicolumn{2}{|c|}{40686} \\
\hline rho & \multicolumn{2}{|c|}{$-0.308^{* * *}$} & & $* * *$ & & \\
\hline & & & & & & \\
\hline
\end{tabular}

Note: Values of $z$ statistics in brackets. * significant at $10 \%$ level, ** significant at $5 \%$ level, $* * *$ significant at $1 \%$ level.

Source: own elaboration. 
The outcomes of the bivariate probit model confirm the robustness of the obtained results. The data set used in the study consists in enterprises registered in a variety of countries that are heterogenous e.g. in terms of the level of the economic development and public policies concerning innovations. The next steps of the empirical research deepen the analysis by estimating a bivariate probit model of the same specification on three subsamples of the original database. The analysis is completed separately for Spanish, German and Bulgarian firms. The choice of countries is supported by two-fold arguments.

Firstly, the size of the subsamples of enterprises from these three countries are representative (as they constitute the largest three groups in the original sample). Furthermore, such analysis constitutes a robustness check providing the answer of whether the obtained results hold for both long-term EU members with a sound economy (such as Germany and Spain) and relatively new members characterized by lower levels of the economic indices. The results are presented in the Appendix (Table 9 and Table 10). The general conclusions emerging from the research presented so far hold for Spanish and German enterprises and not for Bulgarian firms, where in the majority of cases the reception of public funding does not influence the probability of engagement into innovating activities. Such outcomes indicate that public policies aimed at the enhancement of innovativeness in Bulgaria are ineffective. This may be attributed to a variety of reasons such as weakness of institutions, bureaucracy, and corruption. Spain and Germany, as member states of the European Union for a much longer period than Bulgaria, have a better institutional environment supporting the effective functioning of public funding of innovativeness. Such a conclusion is supported by the value of the European Quality of Government Index (Charron et al. 2016) published in a survey funded by the European Commission for Regional Development. The index is constructed on the basis of the results of the survey in which the questions were phrased around the central concepts of quality, impartiality, and corruption. The respondents were asked both about their experience and perceptions regarding the aforementioned issues. In 2013, for the three countries covered by the scope of our analysis, the highest score of the index was reported for Germany (0.8518), and the lowest for Bulgaria (-1.5764). For Spain, the index value was 0.1312. Such an argument is supported by the results of the model described above, indicating the significance of variables such as government's effectiveness and the rule of law.

To conclude, the empirical analysis presented above indicates that the reception of public funding by firms in general should contribute to the higher probability of the introduction of innovation by this firm. However, the efficiency of the public support mechanism may depend on the institutional and economic environments in which it operates. 


\section{CLOSING COMMENTS}

The main goal of the paper was to contribute to a better understanding of the character and effects of public financial support for private innovations developed by firms. Recent cross-disciplinary research regarding the relevance of public support for providing innovations crucial to the market and society that combine economics, legal and political science, reveal the importance of this topic. However, the public support for private firms in order to enable them to provide innovations seems to remain a sophisticated lacuna that should be exploited more.

In European economies, the discrepancies between countries in terms of the innovativeness level of their economies, are very high. This is linked with the character of innovations, types of innovators and public policies executed as an incentive to create crucial innovations. Thus, the observable effects are, to some extent, misleading. However, they are grounds for providing some realistic arguments in the debate about future plans regarding innovativeness.

The question is whether public support for private firms to create market innovations is really operative and effective. In fact, inappropriately large sums of public funds may be wasted on supporting research and development in firms. On the other hand, sometimes it is almost impossible or very time consuming to create disruptive innovations without large external sources of financing. Policymakers are usually aware of the fact that just a fraction of firms putting their assets into creating innovations, will be successful. Thus, the challenge is to minimize the number of beneficiaries that do not succeed.

The impact of public support has different impact on start-ups and large corporations. Large, multinational corporations are able to invest their own assets in R\&D. The creation of innovations could even become part of their strategy. Such corporations are usually better prepared for applying for funds. They can also be skilled in managing complex projects. A number of papers suggest that a higher risk of failure is associated with start-ups. However, their innovations may have an enormous impact and turn them into big firms very quickly. Policies supporting several types of firms are desired.

The results of the empirical model regarding public support for private commercial innovations in European Union countries reveal that local, government and EU public funding exert a positive influence on all types of innovations mentioned in the study. This outcome was confirmed by two types of models - a simple probit model and a bivariate probit model accounting for interaction between process and product innovations. Moreover, the outcomes indicate the importance of the institutional environment for the effective functioning of the public funding of innovations. 
The presented approach constitutes a novelty with respect to the existing literature as it enriches the theoretical considerations about public support with empirical research based on the up to date and detailed data concerning innovativeness in the EU. What is more, the authors focused on a range of types of innovations and funding, which enabled to analyse this phenomenon in many dimensions.

The authors believe that applying the proposed approach, linking theoretical and empirical economic literature with actual studies on public policies, is an added value, and it also serves as a significant contribution to the international literature. A more systematic empirical analysis may allow for formulating more reliable and scientifically-based recommendations on public policies in order to create a formal setting conducive to the optimal functioning of the innovation ecosystem. This may allow for a more successful quest for the possibly most appropriate public support programs in the future, responding to the needs of advanced economies as well as those of emerging markets and developing states.

\section{REFERENCES}

Acemoglu, D., Akcigit, U., Bloom, N., Kerr, W. R., Innovation, Reallocation and Growth, NBER Working Paper Series No.18993, 2013.

Acharya, V. V., Subramanian, K. V. , Bankruptcy Codes and Innovation, NBER working Paper, 16484, 2009.

Acharya, V. V.,, Baghai, R. P., Subramanian, K. V. , Labor Laws and Innovation, The Journal of Law and Economics, 56 (4), pp. 997-1037, 2013.

Z. J. Acs, Z. J. , D. B. Audretsch, D. B., Innovation in Large and Small Firms: An Empirical Analysis, "The American Economic Review", 78 (4), pp. 678-690, 1988.

Aghion, P., Howitt, P., A Model of Growth through Creative Destruction, "Econometrica", 60 (2), pp. 323-351, 1992.

Aghion, P., Bloom, N., Blundell, R., Griffith, R., Howitt, P., Competition and Innovation: An Inverted-U Relationship, The Quarterly Journal of Economics, 120 (2), pp. 701-728, 2005.

Aghion, P., Blundell, R., Griffith, R., Howitt, P., Prantl, S., The Effects of Entry on Incumbent Innovation and Productivity, "The Review of Economics and Statistics", 91 (1), pp. 20-32, 2009.

Akiyama, T. , Furukawa, Y. Intellectual Property Rights and Appropriability of Innovation, "Economics Letters", 103 (3), pp. 138-141, 2009.

Almeida, R., Fernandes, A. M., Openness and Technological Innovations in Developing Countries: Evidence from Firm-Level Surveys, The World Bank, 2008.

Andrews, D., Cingano, F. , Public Policy and Resource Allocation: Evidence from Firms in OECD Countries, OECD Economics Department Working Papers No. 996, 2012. 
Andrews, D., Criscoulo, C., Menon, C., Do Resources Flow to Patenting Firms? Cross-Country Evidence from Firm Level Data, OECD Economics Departments Working Papers No. 1127, 2014.

Andrews, D., Criscoulo, C., Gal, P., (2015), Frontier Firms, Technology, Diffusion and Public Policy: Micro Evidence from OECD Countries, OECD Productivity Working Papers No. 02, 2015.

Audetsch, D. B., Sustaining Innovation and Growth: Public Policy Support for Entrepreneurship, "Industry and Innovation", 11 (3), pp. 167-191, 2004.

Baldwin, J. R., Johnson, J., Human Capital Development and Innovation: The Case of Training in Small and Medium-Sized Firms, Statistics Canada Working Paper No. 74, 1996.

Bassanini, A., Scarpetta, S., Hemmings, P., Economic Growth: The Role of Policies and Institutions. Panel Data. Evidence from OECD Countries, OECD Economics Departments Working Papers No. 283, 2001.

Bessen, J., Maskin, E., Sequential Innovation, Patents, and Imitation, "RAND Journal of Economics", 40 (4), pp. 611-635, 2009.

Bilbao-Osorio, B., Rodriguez-Pose, A., From R\&D to Innovation and Economic Growth in the EU, "Growth and Change", 35 (4), pp. 434-455, 2004.

Blundell, R., Dearden, L., Meghir, C., Sianesi, B., Human Capital Investment: The Returns from Education and Training to the Individual, the Firm and the Economy, "Fiscal Studies", 20 (1), pp. 1-23, 1999.

Breschi, S., Lissoni, F., Knowledge Spillovers and Local Innovation Systems: A Critical Survey, "Industrial and Corporate Change", 10 (4), pp. 975-1005, 2001.

Boldrin, M., Levine, D.K. , Rent-Seeking and Innovation, "Journal of Monetary Economics", 51 (1), pp. 127-160, 2004.

Boldrin, M., Levine, D.K., Against Intellectual Monopoly, "Syracuse Science \& Technology Law Reporter", 130, pp. 1-15, 2009.

Bottazzi, L., Peri, G. (2003), Innovation and Spillovers in Regions: Evidence from European Patent Data, "European economic review", 47 (4), pp. 687-710.

Bouis, R., Duval R. , Murtin, F., The Policy and Institutional Drivers of Economic Growth Across OECD and Non-OECD Economies. New Evidence from Growth Regressions, OECD Economics Departments Working Papers No. 843, 2011.

Carlino, G., Kerr, W. R., Agglomeration and Innovation, NBER Working Paper No. 20367, 2014.

Cecchetti, S., Kharroubi, E., Why Does Financial Sector Growth Crowd Out Real Economic Growth?, CEPR Discussion Paper No.27, 2015.

Charron, N., Dahlberg, S., Holmberg, S., Rothstein, B, Khomenko, A., Svensson, R., The Quality of Government EU Regional Dataset, version Sep16. University of Gothenburg: The Quality of Government Institute, 2016, https://www.gu.se/en/quality-government/qogdata/data-downloads/eu-regional dataset?fbclid=IwAR1otGN0Tjw-eUw9LVkkeLvSGIeP m3F5mBKHFuACU_7YBzYa_amPWojZozU.

Chen, Y., Puttitanun, T. (2005), Intellectual property rights and innovation in developing countries, "Journal of development economics", 78 (2), pp. 474-493, 2005. 
Cingano, F., Leonardi, M, Messina,J., Pica, G., The Effects of Employment Protection Legislation and Financial Market Imperfections on Investment: Evidence from a FirmLevel Panel of EU Countries, "Economic Policy”, 25 (61), pp. 117-163, 2010.

Davis, L. S., Sener, F., Private Patent Protection in the Theory of Schumpeterian Growth, "European Economic Review", 56, pp. 1446-1460, 2012.

D’Este, P., Iammarino, S., Savona, M., von Tunzelmann, N., What Hampers Innovation? Revealed Barriers Versus Deterring Barriers, "Research Policy", 41 (2), pp. 482-488, 2012.

Dogdson, M., Hughes, A., Foster, J., Metcalfe, S. (2011), Systems Thinking, Market Failure, and the Development of Innovation Policy: The Case of Australia, "Research Policy", 40 (9), pp. 1145-1156, 2011

Edwards, S. , Openness, Productivity and Growth: What Do We Really Know?, "The Economic Journal", 108 (447), pp. 383-398, 1998.

European Commission, A Study on R\&D Tax Incentives, 2014.

Eurostat, Community Innovation Survey, 2012.

Fagerberg, J., A Technology Gap Approach to Why Growth Rates Differ, "Research Policy", 16 (2-4), pp. 87-99, 1987.

Falvey, R., Foster, N., Greenaway D., Intellectual Property Rights and Economic Growth, "Review of Development Economics", 10 (4), pp. 700-719, 2006.

Felbermayr, G. J., Yalcin, E., Export Credit Guarantees and Export Performance: An Empirical Analysis for Germany, “The World Economy”, 36 (8), pp. 700-719, 2013.

Fischer, M. M. , Innovation, Knowledge Creation and Systems of Innovation, "The Annals of Regional Science”, 35 (2), pp. 199-216, 2001.

Frank, K. A., Zhao, Y., Borman, K., Social Capital and the Diffusion of Innovations Within Organizations: The Case of Computer Technology in Schools, "Sociology of Education", 77 (2), pp. 148-171, 2004.

Freeman, Ch., Soete, L., The Economics of Industrial Innovation, The MIT Press, Cambridge, 1997.

Furukawa, Y., The Protection of Intellectual Property Rights and Endogenous Growth: Is Stronger Always Better?, "Journal of Economic Dynamics and Control", 31 (11), pp. 3644-3670, 2007.

Furukawa, Y., Intellectual Property Protection and Innovation: an Inverted-U Relationship, "Economics Letters", 109 (2), pp. 99-101, 2010.

Geroski, P. E., Innovation, Technological Opportunity, and Market Structure, "Oxford Economic Papers", 42 (3), pp. 586-602, 1990.

Gilbert, R. J. , Competition and Innovation, “Journal of Industrial Organization Education”, 1 (1), pp. 1.23, 2006.

Gonzales, X., Joumandreu, J., Pazo, C., Barriers to Innovation and Subsidy Effectiveness, "RAND Journal of Economics", 36 (4), pp. 930-950, 2005.

Griliches, Z., , The Search for R\&D Spillovers, "Scandinavian Journal of Economics", 94 (0), pp. 29-47, 1992.

Grossman, G. M., Helpman, E., Innovation and Growth in the Global Economy, The MIT Press, Cambridge, 1991. 
Grossman, G. M., Helpman, E. , Endogenous Innovation in the Theory of Growth, "The Journal of Economic Perspectives", 8 (1), pp. 23-44, 1994.

Ha, J., Howitt, P., Accounting for Trends in Productivity and R\&D: A Schumpeterian Critique for Semi-Endogenous Growth Theory, "Journal of Money, Credit and Banking", 39 (4), pp. 733-774, 2007.

Harrison, A, Openness and Growth: A Ttime-series, Cross-country Analysis for Developing Countries, "Journal of Development Economics", 48 (2), pp. 419-447, 1996.

Hatch, N. W., Dyer, J. H., Human Capital and Learning as a Source of Sustainable Competitive Advantage, "Strategic Management Journal", 25 (12), pp. 1155-1178, 2004.

Hovernkamp, H. , Competition for Innovation, “Columbia Business Law Review”, 799, 2012.

Hsu, P-H., = Tian, X., Xu, Y., Financial Development and Innovation: Cross-country Evidence, "Journal of Financial Economics", 112 (1), pp. 116-135, 2014.

Jaumotte, F., Pain, N., An Overview of Public Policies to Support Innovation, OECD Economics Department Working Papers No. 456, 2005.

Jensen, M. B., Johnson, B., Lorenz, E., Lundvall, B.A, Forms of Knowledge and Modes of Innovation, "Research Policy", 36 (5), pp. 680-693, 2007.

Jones, C. I., R\&D-Based Models of Economic Growth, “Journal of Political Economy”, 103 (4), pp. 759-784, 1995.

Kaufmann, D., Kraay A., Worldwide Governance Indicators, 2016, http://www.govindicators. org

Keller, W., International Technology Diffusion, "Journal of Economic Literature", 42 (3), pp. 752-782, 2004.

Kim, Y. K., Lee, K., Park, W. G., Choo, K., Appropriate Intellectual Property Protection and Economic Growth in Countries at Different Levels of Development, "Research Policy", 41, pp. 358-375, 2012.

Klapper, L., Laevena, L., Rajan, R., Entry Regulation as a Barrier to Entrepreneurship, “Journal of Financial Economics", 82, pp. 591-629, 2006.

Landry, R., Amara, N., Lamari M., Does Social Capital Determine Innovation? To What Extent?, "Technological Forecasting and Social Change", 69 (7), pp. 681-701, 2002.

Laursen, K., Salter, A., Open for Innovation: the Role of Openness in Explaining Innovation Performance Among U.K. Manufacturing Firms, Strategic Management, 27 (2), pp. 131-150, 2005.

Lawson, C., Lorenz, E., Collective Learning, Tacit Knowledge and Regional Innovative Capacity, Regional Studies, 33 (4), pp. 305-317, 2010.

Lederman, D., Klinger, B., Diversification, Innovation, and Imitation Inside The Global Technological Frontier, Policy Research Working Papers, 2006.

Levine, R. (1997), Financial Development and Economic Growth: Views and Agenda, "Journal of Economic Literature", 35 (2), pp. 688-726, 1997.

Liu, X., Buck, T., Innovation Performance and Channels for International Technology Spillovers: Evidence from Chinese High-tech Industries, "Research Policy”, 36 (3), pp. 355-366, 2007.

Love, J. H., Roper, S., The Determinants of Innovation: R\&D, Technology Transfer and Networking Effects, "Review of Industrial Organization", 15 (1), pp. 43-64, 1999. 
Madrid-Guijarro, A., Garcia, D., Van Auken, H., Barriers to Innovation among Spanish Manufacturing SMEs, "Journal of Small Business Management Journal”, 47 (4), pp. 465-488, 2009.

Madsen, J. B, Semi-Endogenous versus Schumpeterian Growth Models: Testing the Knowledge Production Function Using International Data, "Journal of Economic Growth", 13, pp. 1-26, 2008.

Mansfield, E., The R\&D Tax Credit and Other Technology Policy Issues, "The American Economic Review", 76 (2), pp. 190-194, 1986.

Mansfield, E., Switzer, L., The Effects of $R \& D$ Tax Credits and Allowances in Canada, "Research Policy", 14 (2), pp. 97-107, 1985.

Mansfield, E., Rapoport, J., Romeo, A., Wagner, S., Beardsley, G., , Social and Private Rates of Return from Industrial Innovation, "The Quarterly Journal of Economics", 91 (2), pp. 221-240, 1997.

Martin, S., Scott, J. T., The Nature of Innovation Market Failure and the Design of Public Support for Private Innovation, "Research Policy", 29 (4-5), pp. 437-447, 2000.

Melnikas, B., The Knowledge-Based Economy in the European Union: Innovations, Networking and Transformation Strategies, "Transformation in Business \& Economics", 7, pp. 170-192, 2008.

Murray,F., Stern, S., Do Formal Intellectual Property Rights Hinder the Free Flow of Scientific Knowledge? An Empirical Test of the Anti-Commons Hypothesis, "Journal of Economic Behavior \& Organization", 63, pp. 648-687, 2007.

Mytelka, L. K. , Local Systems of Innovation in a Globalized World Economy, "Industry and Innovation", 7 (1), pp. 15-32, 2010.

Nunn, N., Relationship-Specificity, Incomplete Contracts, and the Pattern of Trade, "The Quarterly Journal of Economics", 122 (2), pp. 569-600, 2007.

OECD, Business Clusters: Promoting Enterprise in Central and Eastern Europe, OECD Publishing, 2005.

OECD, R\&D Tax Incentives: Rationale, Design, Evaluation, OECD Publishing, 2010.

OECD, OECD Science, Technology and Industry Outlook, OECD Publishing, 2014.

Palazzi, P., Taxation and Innovation, OECD Taxation Working Papers No. 9, 2011.

Park, W. G., Ginarte, J. C. , Intellectual Property Rights and Economic Growth, "Contemporary Economic Policy”, 15 (3), pp. 51-61, 1997.

Pihkala, T., Ylinenpaa, H., Vesalainen, J., Innovation Barriers Amongst Clusters of European SMEs, "International Journal of Entrepreneurship and Innovation Management", 2 (6), pp. 520-536, 2002.

Romer, P. M., Endogenous Technological Change, "Journal of Political Economy", 98 (5), pp. 71-102, 1990.

Saint-Paul, G. ,Employment protection, international specialization, and innovation, "European Economic Review", 46 (2), pp. 375-395, 2002.

Schumpeter, J., The Theory of Economic Development: An Inquiry into Profits, Capital, Credit, Interest, and the Business Cycle, Transaction Publishers, Cambridge, 1934.

Solow, R. M. , Perspectives on Growth Theory, “The Journal of Economic Perspectives”, 8 (1), pp. 45-54, 1994. 
Stokey, N. L., R\&D and Economic Growth, "The Review of Economic Studies", 62 (3), pp. 469-489, 1995.

Suorsa, K., Regionality, Innovation Policy and Peripheral Regions in Finland, Sweden and Norway, "EBSCO Academic Search Premier", 185 (1), pp. 15-29, 2007.

Sylwester, K., R\&D and Economic Growth, "Knowledge, Technology \& Policy", 13 (4), pp. 71-84, 2001.

Tang, J. , Competition and Innovation Behaviour, "Research Policy", 35 (1), pp. 68-82, 2006.

Thompson, M. A., Rushing, F. W. , An Empirical Analysis of the Impact of Patent Protection on Economic Growth: An Extension, "Journal of Economic Development", 24 (1), pp. 67-76, 1999.

Varsakelis, N. C., The Impact of Patent Protection, Economy Openness and National Culture on R\&D Investment: a Cross-country Empirical Investigation, "Research Policy", 30 (7), pp. 1059-1068, 2001.

Verspagen, B., Endogenous Innovation in Neoclassical Growth Models: A Survey, "Journal of Macroeconomics", 14 (4), pp. 631-662, 1992.

Vinnova Analysis, Innovations and New Technology - What is the Role of Research? Implications for Public Policy, VA No. 2014:05, 2014.

Wallsten, S. J., The Effects of Government-Industry R\&D Programs on Private R\&D: the Case of the Small Business Innovation Research Program, "RAND Journal of Economics", 31 (1), pp. 82-100, 2000.

Warwick, K., Nolan, A., Evaluation of Industrial Policy: Methodological Issues and Policy Lessons, OECD Science, Technology and Industry Policy Papers No. 16., 2014.

Received: April 2018, revised: October 2018 


\section{APPENDIX}

Table 6

Descriptive statistics

\begin{tabular}{|c|c|c|c|}
\hline & Value & Frequency & Percentage \\
\hline \multirow[t]{2}{*}{ inpdgd } & 0 & 32,000 & 78.90 \\
\hline & 1 & 8,556 & 21.10 \\
\hline \multirow[t]{2}{*}{ inpdsv } & 0 & 35,774 & 88.21 \\
\hline & 1 & 4,782 & 11.79 \\
\hline \multirow[t]{2}{*}{ inpspd } & 0 & 32,858 & 81.02 \\
\hline & 1 & 7,698 & 18.98 \\
\hline \multirow[t]{2}{*}{ inpslg } & 0 & 37,819 & 93.25 \\
\hline & 1 & 2,737 & 6.75 \\
\hline \multirow[t]{2}{*}{ inpssu } & 0 & 33,905 & 83.60 \\
\hline & 1 & 6,651 & 16.40 \\
\hline \multirow[t]{2}{*}{ funloc } & 0 & 37,824 & 93.26 \\
\hline & 1 & 2,732 & 6.74 \\
\hline \multirow[t]{2}{*}{ fungmt } & 0 & 35,947 & 88.64 \\
\hline & 1 & 4,609 & 11.36 \\
\hline \multirow[t]{2}{*}{ funeu } & 0 & 38,148 & 94.06 \\
\hline & 1 & 2,408 & 5.94 \\
\hline \multirow[t]{2}{*}{ size 500} & 0 & 38,687 & 95.39 \\
\hline & 1 & 1,869 & 4.61 \\
\hline \multirow[t]{2}{*}{ size 250} & 0 & 37,979 & 93.65 \\
\hline & 1 & 2,577 & 6.35 \\
\hline \multirow[t]{2}{*}{ size50 } & 0 & 28,737 & 70.86 \\
\hline & 1 & 11,819 & 29.14 \\
\hline \multirow[t]{2}{*}{ size0 } & 0 & 16,265 & 40.11 \\
\hline & 1 & 24,291 & 59.89 \\
\hline
\end{tabular}

Source: own elaboration.

Table 7

Descriptive statistics

\begin{tabular}{l|c|c|c|c|c}
\hline \multicolumn{1}{c|}{ Variable } & Number of observations & Mean & Std. Dev. & Min & Max \\
\hline rallx_rat & 40,556 & 11.18053 & 1046.471 & 0 & 146776.8 \\
\hline turn12 & 40,556 & $39,000,000$ & $389,000,000$ & 511 & $31,500,000,000$ \\
\hline empud & 40,556 & 2.586498 & 1.864155 & 0 & 6 \\
\hline gdppc & 40,556 & 27817.6 & 7870.694 & 7378.025 & 44065.25 \\
\hline infl & 40,556 & 2.522438 & .6102502 & 2 & 5.7 \\
\hline gov & 40,556 & 1.09656 & .3702416 & -.3119554 & 1.829577 \\
\hline rol & 40,556 & 1.022435 & .3607303 & -.085205 & 1.664948 \\
\hline taxr & 40,556 & 25.79908 & 5.109495 & 7.9 & 28.4 \\
\hline open & 40,556 & 70.25723 & 24.70558 & 59.9 & 179.2 \\
\hline
\end{tabular}

Source: own elaboration. 
INCENTIVES FOR PRIVATE INNOVATIONS...

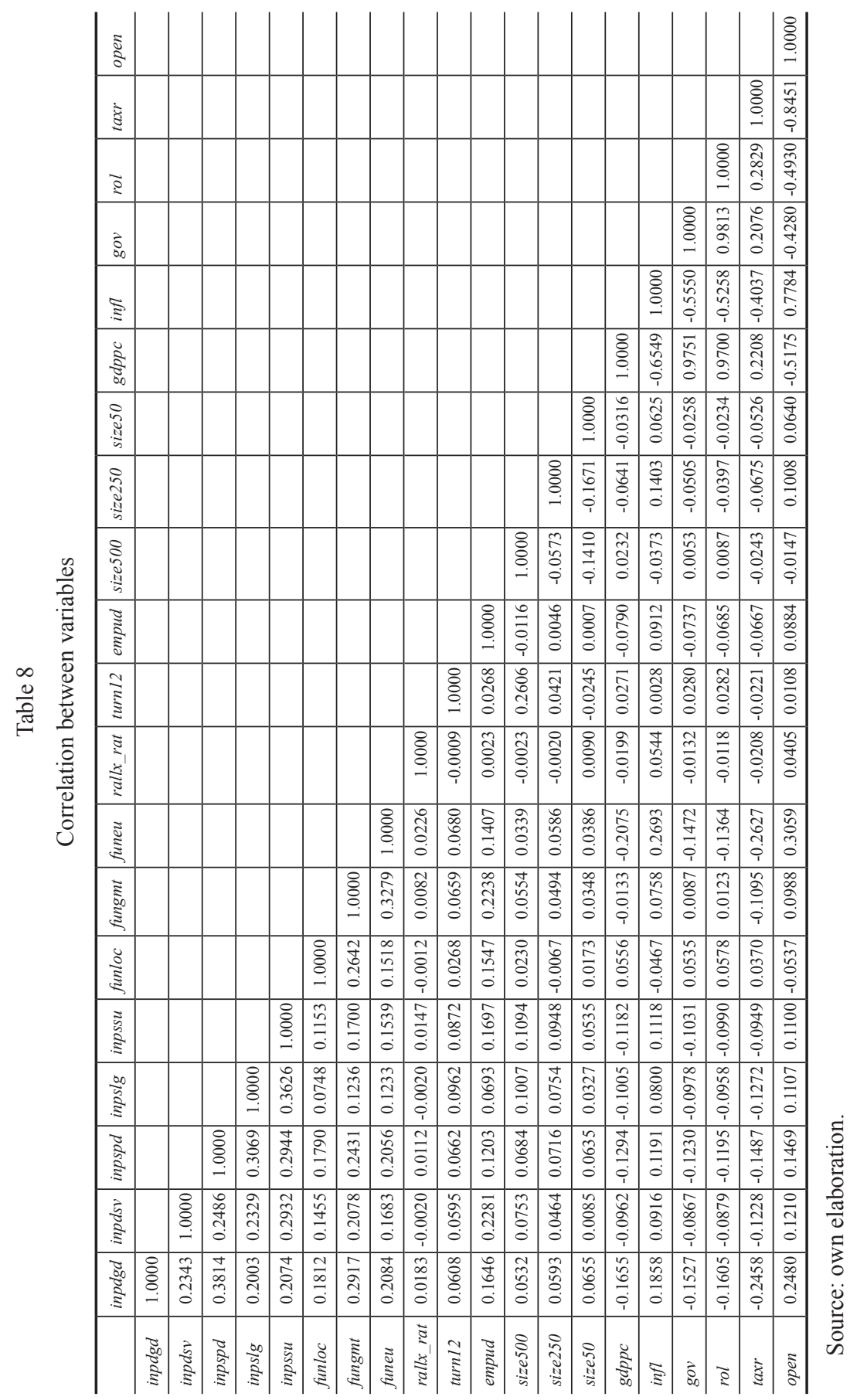




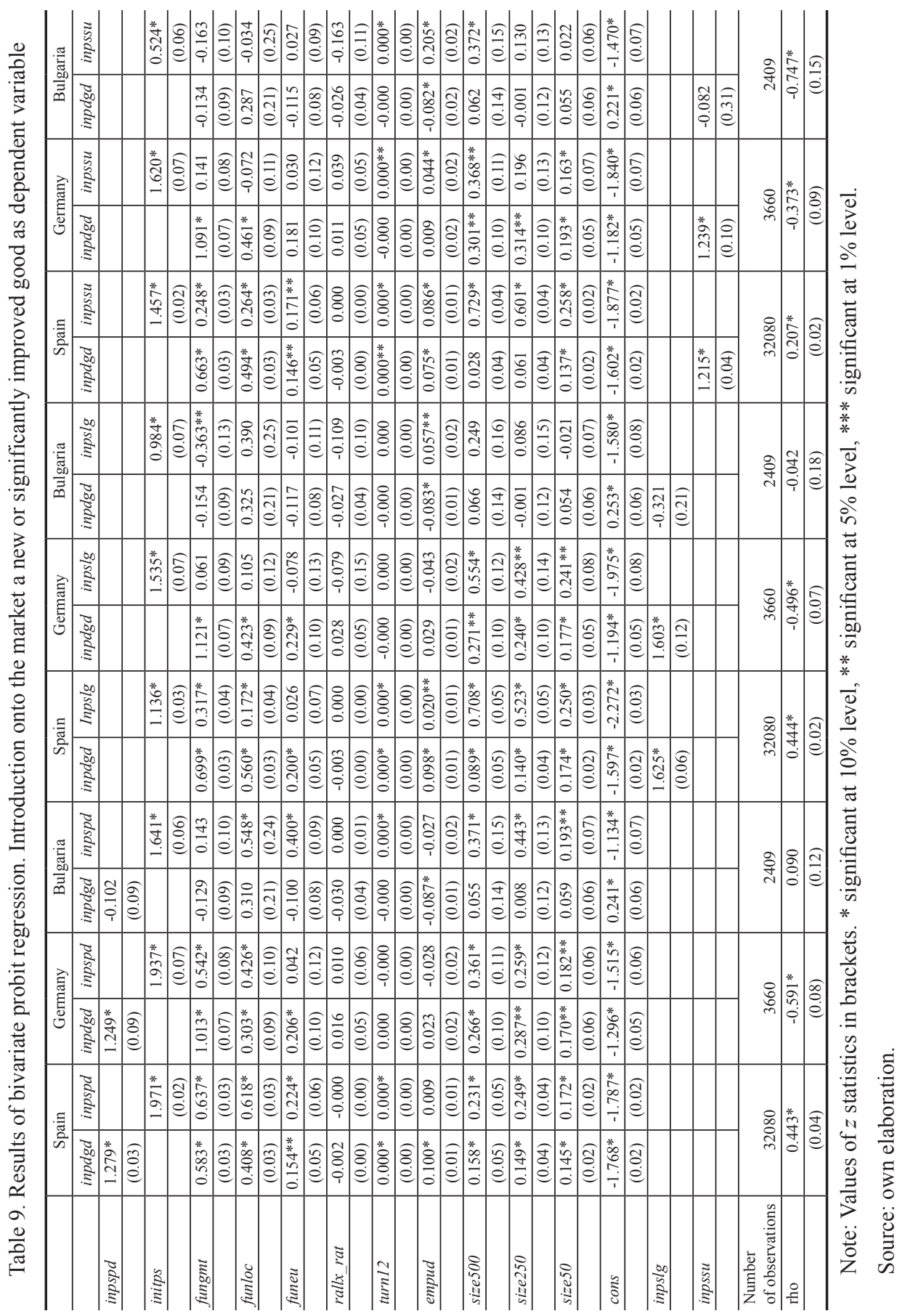




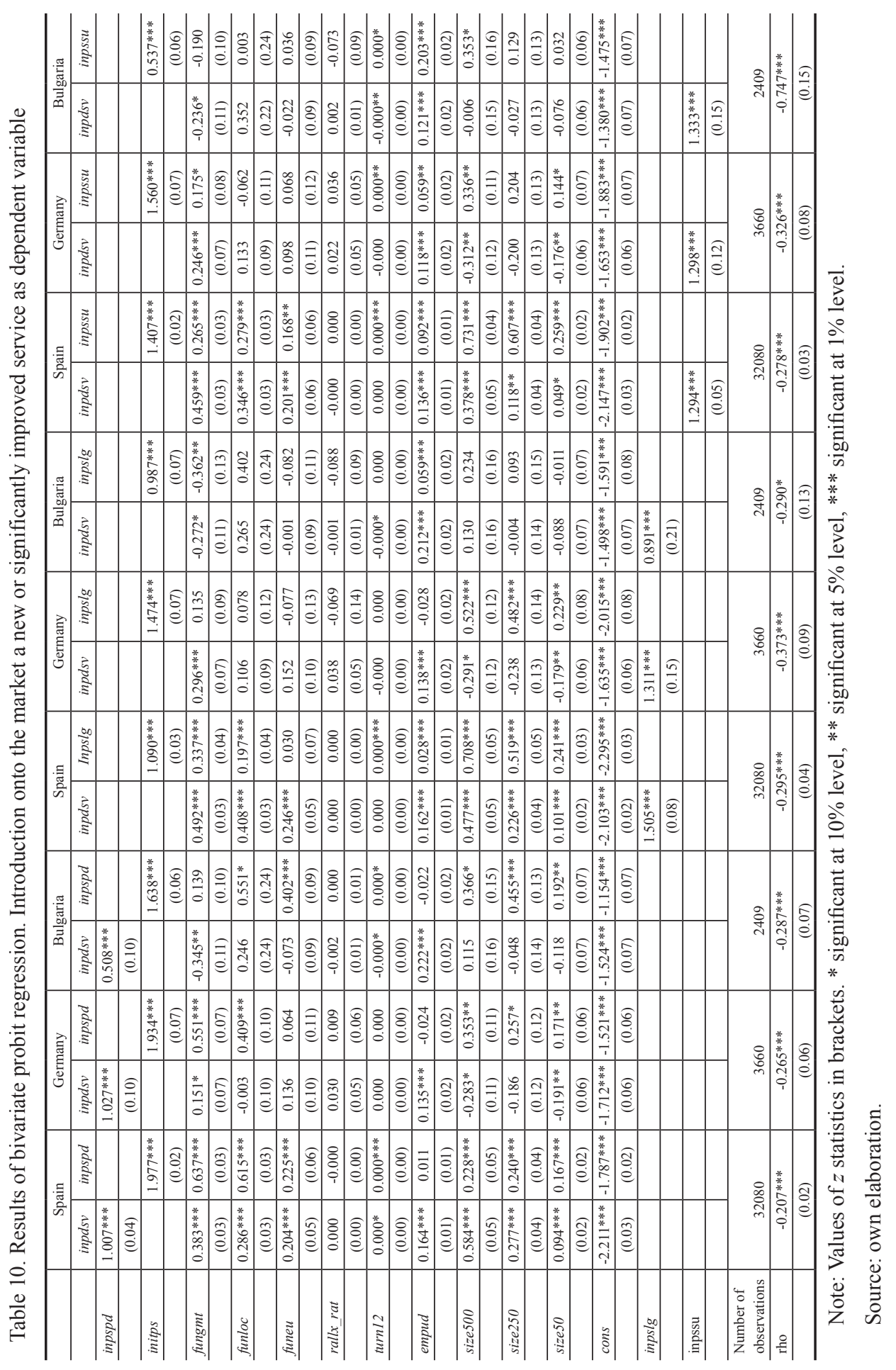

